\title{
AEROBIC BIOLOGICAL TREATABILITY STUDIES ON LANDFILL LEACHATE WITH NITRIFICATION AND DENITRIFICATION
}

\author{
Tim Robinson *
}

Phoenix Engineering, Phoenix House, Scarne Mill Industrial Estate, Launceston, Cornwall, PL15 9GL, United Kingdom

Article Info:
Received:
01 March 2019
Revised:
07 June 2019
Accepted:
02 July 2019
Available online:
01 August 2019
Keywords:
Ammoniacal-N removal
Biological treatment
Denitrification
Landfill leachate
Leachate treatment
Nitrification
Treatability trials

Article Info:

01 March 2019

Revised:

07 June 2019

Available online:

01 August 2019

Ammoniacal-N removal

Biological treatment

Denitrification

Landill leachate

Treatability trials

\begin{abstract}
Large pilot-scale treatment trials have examined the treatment of a leachate typical of those found at many closed landfill sites, containing approximately $200 \mathrm{mg} / \mathrm{l}$ of ammoniacal-N. At such sites, treatment of these leachates with nitrification of ammoniacal-N alone, will not allow discharges of treated leachate to be made into sensitive surface watercourses, because of concerns about nitrate- $\mathrm{N}$. The trials therefore included denitrification processes, by modification of an SBR process configuration, using the waste product glycerol, widely available as a by-product from the production of biodiesel, as the carbon source for denitrification. Initially a nitrification-only Stage 1 treatment trial treated strong, methanogenic leachate containing $2000 \mathrm{mg} / \mathrm{l}$ of ammoniacal-N and $4000 \mathrm{mg} / \mathrm{l} \mathrm{COD}$, completely nitrifying all ammoniacal-N to nitrate-N. Following the successful treatment of strong leachate through nitrification, the innovative combined nitrification and denitrification treatment system was constructed. Stage 2 of the treatability trial used this newly designed system to incorporate both aeration and anoxic phases within a single reactor; enabling full nitrification and denitrification of weaker leachate from a closed landfill, containing $150 \mathrm{mg} / \mathrm{l} \mathrm{am}$ moniacal-N and 200mg/I COD. In particular, the development of an innovative, stable, robust and relatively simple combined nitrification and denitrification process will have wide application at many closed landfill sites, where a reliable and robust treatment process is required, whilst full denitrification of nitrate- $\mathrm{N}$ is essential if treated leachate is to be discharged locally into small watercourses. The relative simplicity of the new process, in a single tank, with readily-automated operation and few chemical additions, means that it can be used at remote closed landfills, to produce high quality effluents suitable for discharge into many surface watercourses.
\end{abstract}

\section{INTRODUCTION}

The reliable and consistent on-site treatment of leachate is now a common requirement at modern landfill sites. That treatment must achieve complete removal of all degradable organic compounds in the leachate, as well as nitrification, and increasingly denitrification, of very high concentrations of ammoniacal nitrogen and nitrate nitrogen.

Aerobic biological processes have widely been shown to be capable of achieving these treatment objectives, and the Sequencing Batch Reactor (SBR) process configuration has been used successfully in many countries, and regularly shown to provide the robustness of treatment required (Environment Agency, 2007). However, an effective method of treating medium strength leachates from closed landfills, whilst incurring low running, operational and maintenance costs has yet to be adopted; whereby both nitrification and denitrification are successfully achieved within a single reactor, prior to appropriate discharges to sensitive watercourses.

The study reported in this paper first involved proving the success of large pilot scale treatment studies at treating strong methanogenic leachate through nitrification, which is very typical of leachates from large landfill sites in many countries of the world (Christensen, 2011).

At many closed landfill sites however, treatment of weaker leachates (containing approximately 200mg/l of ammoniacal-N) with nitrification only will not allow discharges of treated leachate into highly sensitive surface watercourses (Wilson, et al., 2015), because of concerns about nitrate-N and possible eutrophication problems. Therefore, the Stage 2 treatability trial incorporated the denitrification process, by modification of the process configuration, to provide complete nitrification and denitrification within a single treatment reactor.

Full scale leachate treatment plants which not only achieve nitrification of high concentrations of ammonia- 
cal-N, but also full denitrification of the nitrite-N produced, have been designed and commissioned in recent years (Robinson, 2007). The Vissershok plant at the main landfill serving the city of Cape Town is one such plant, designed to treat more than $400 \mathrm{~m}^{3} / \mathrm{d}$ of leachate containing more than $2000 \mathrm{mg} / \mathrm{l}$ of ammoniacal-N (Plate 1). The full-scale Vissershok plant has two aeration tanks, overflowing into an anoxic tank, before being transferred into a post anoxic tank and an ultra-filtration unit.

Such large plants, although demonstrated to be capable of reliable and robust operation, are relatively complex, and generally require daily attendance by a plant operator. In particular, the process of nitrification, denitrification and post anoxic aeration take place in separate reactors, as follows, so that acidity produced during nitrification, and alkalinity generated during denitrification, can balance each other to minimize addition of $\mathrm{pH}$ chemicals, as mixed liquor circulates around the various reactors (Robinson, et al., 2017).

It would not be possible to operate such a plant in a single reactor, because alternating nitrification during Aerobic phases, denitrification during Anoxic phases, and aeration during Post-Anoxic Aeration phases, would cause wide swings in $\mathrm{pH}$ value, which would be damaging to both nitrifying and denitrifying bacteria. The Stage 2 trials would therefore investigate whether treatment of weaker leachates, found at many hundreds of older closed landfills in the UK, could achieve complete nitrification and denitrification of ammoniacal- $\mathrm{N}$ in a simpler, single reactor system.

The paper describes the design and operation of both Stage 1 and Stage 2 of the trials, presenting detailed analytical and operational results, and discusses the implications of these.

\section{MATERIALS AND METHODS}

The same 240-litre capacity pilot-scale treatment unit was used for Stage 1 nitrification trials on strong leachates and Stage 2 combined nitrification and denitrification trials on weaker leachate from a closed landfill. The unit was constructed as shown in Plate 2 and was modified to allow anoxic mixing and carbon dosing during the denitrification phase of the Stage 2 Trials.

\subsection{Stage 1 Experimental Design}

The strong methanogenic leachate treated during Stage 1 contained COD values of about $4000 \mathrm{mg} / \mathrm{l}$, and concentrations of ammoniacal-N of just below $2000 \mathrm{mg} / \mathrm{l}$. This trial achieved the degree of nitrification treatment required, demonstrating that no leachate contaminants were causing inhibition to complete ammoniacal-N removal.

Figure 1 displays the design of the treatment unit used during Stage 1, to allow operation in a fully-automated way, as a Sequencing Batch Reactor (SBR). The aerated reactor had a minimum operating volume of 160 litres, and could be aerated and mixed by means of a fine air diffuser pipe in the base, which received air from a small electric compressor, controlled by a simple timer. Dosing of leachate for treatment was provided by a small dosing pump, mounted on a 100-litre capacity feed tank.

Pre-set volumes of leachate were dosed into the reactor every 15 minutes during aeration periods. Following a daily period of quiescent settlement, clarified effluent was decanted over a small bellmouth weir, when a small solenoid valve was energized by a timer, and opened.

A $20 \mathrm{~mm}$ pipe was inserted to act as the bellmouth overflow weir, to allow effluent discharge down to a bottom water level of 160 litres capacity. The discharge

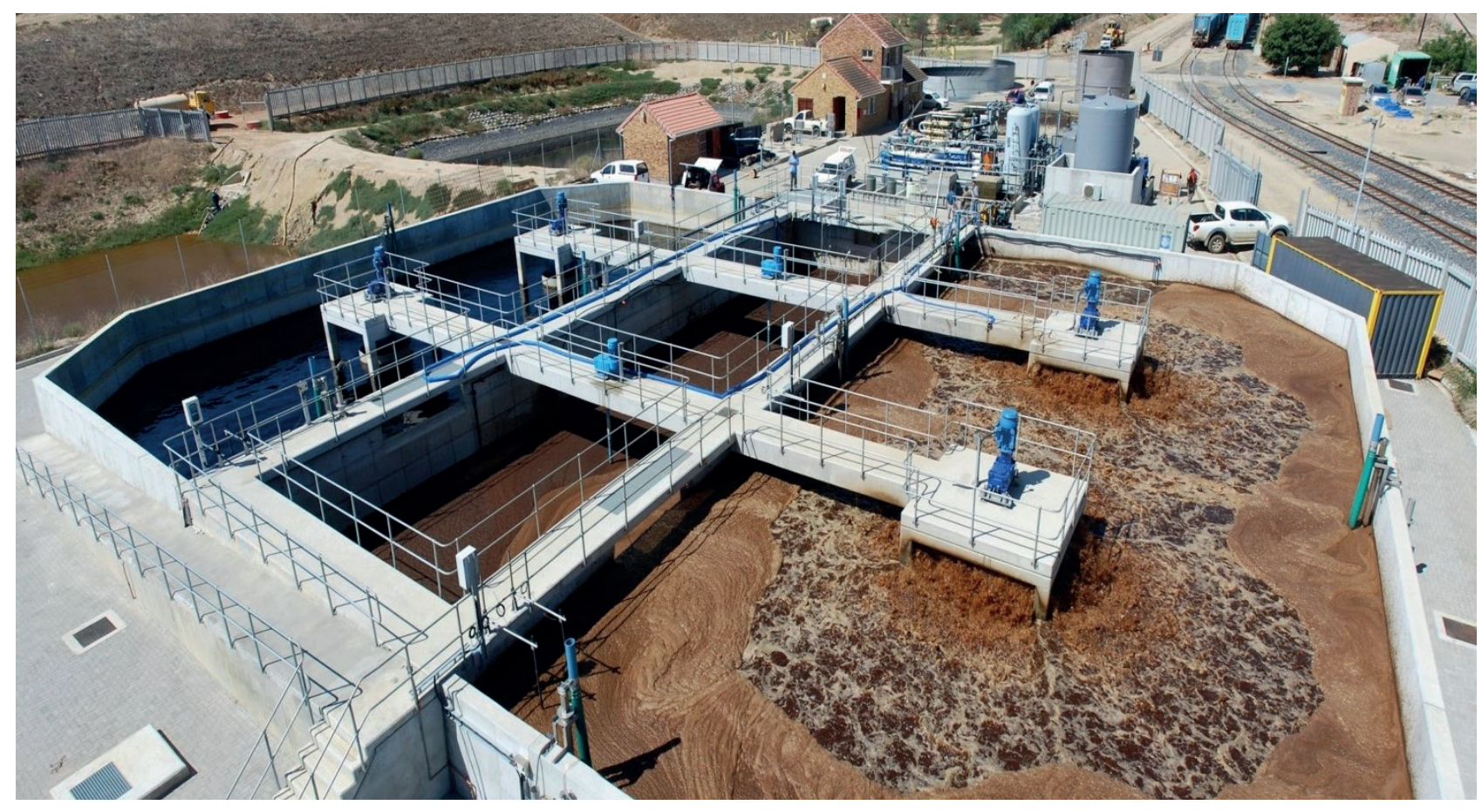

PLATE 1: Vissershok Landfill Leachate Treatment Plant, Cape Town, South Africa. 


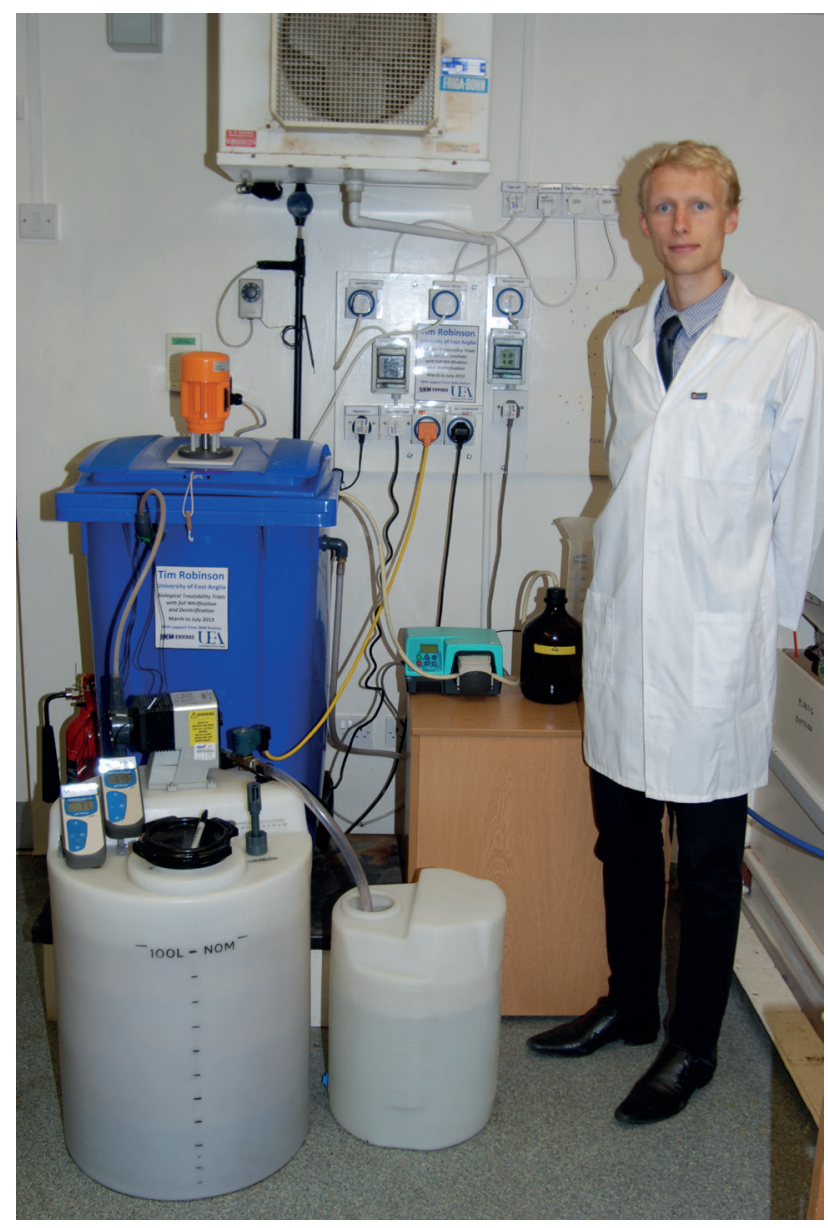

PLATE 2: View of the experimental units, showing feed tank and dosing pump, the 240 litre SBR reactor, electrical control panel, and treated leachate tank.

end of this pipe was fitted with a solenoid valve (CEME $9914 \frac{1}{2}$ "series), which, when energized, opened to allow discharge of treated leachate into an effluent collection container.

To allow nitrification to take place during an aerobic phase, a small $0.25 \mathrm{~kW}$ Compton air compressor (model AMDE $90 \mathrm{~L} / \mathrm{A} 4$ ) supplied aeration via a $25 \mathrm{~mm}$ diameter fine pore diffuser pipe in the base of the unit. This also provided vigorous mixing. Air flow rates from 10 to $35 \mathrm{l} / \mathrm{min}$ through the diffuser could be achieved accurately.

A diaphragm chemical dosing pump (Siemens AA1409 Premia75 Mono Pump) was programmed to dose leachate slowly at precise low rates into the aeration unit every 15 minutes from the 100-litre feed tank. This feed tank was calibrated to allow volumes dosed each day to be measured accurately to the nearest 0.1 litre.

Automated operation of the treatability unit was controlled from an electrical panel, where timers for each device were located in a series of sockets. A 200W tank heater/thermostat maintained treatment temperatures in the range $23-25^{\circ} \mathrm{C}$, which would be typical of a large scale biological treatment plant (Robinson, 2015).

The treatment process was operated on a 24-hour cycle as shown below:
(1) 20 hours: Aeration and leachate addition every 15 minutes.

(2) 2 hours: Quiescent settlement and clarification.

(3) 2 hours: Effluent decant and idle.

$\mathrm{pH}$ values were controlled within an optimum range of 7.2 to 7.8 by manual daily addition of measured amounts of sodium bicarbonate into the reactor. Samples of effluent discharged were tested each day for concentrations of ammoniacal- $\mathrm{N}$, nitrate- $\mathrm{N}$ and nitrite- $\mathrm{N}$, using test strips, and samples of leachate feed, mixed liquor, and treated leachate were submitted to a laboratory once or twice each week, for more detailed analysis.

Leachate to be treated in the initial nitrification only trials was selected to be typical of strong, stable methanogenic leachates that are found at large landfill sites in many countries of the world (Robinson, 2007). 1000 litres of the leachate was obtained from a large landfill site in East Anglia, UK, to be transported in an airtight IBC container to the laboratory, for storage and use in the trials. Regular testing of the leachate feed demonstrated that no significant changes in leachate composition took place during the period of the trials (Table 2 ).

Leachate feeding began on Day 0 , and gradually increased until by Day 10, about 10 litres were being treated each day, at a mean Hydraulic Retention Time (HRT) of about 16 days. Feed rates continued to be increased, and between Days 29 and 45 leachate was being treated at rates of 16 or 17 litres per day with full nitrification. For the last week of the trials, up to Day 54 , dosing rates of 21 or 22 litres per day were consistently treated successfully, however when increased further, to above 25 litres daily, breakthrough of ammoniacal-N took place.

Figure 2 shows the mean HRT (in days) that was maintained during the Stage 1 trials, and Table 2 presents detailed results for the quality of the raw leachate feed, and of treated leachate once stable conditions of operation had been established.

\subsection{Stage 2 Experimental Design}

The initial Stage 1 series of trials had demonstrated that the pilot-scale treatment units which had been designed and constructed, were capable of operating reliably and efficiently to provide stable treatment of a relatively strong methanogenic landfill leachate.

Leachates from closed landfill sites are weaker than those from large operational sites (Kjeldsen et al., 2002), but typically still contain 100 to $200 \mathrm{mg} / \mathrm{l}$ of ammoniacal-N. Furthermore, discharge of treated leachates containing equivalent concentrations of nitrate- $\mathrm{N}$ to watercourse or sewer remains problematic (Robinson, 2017).

The second stage of the trials would therefore examine the practicality of using a single vessel modified SBR process to treat such leachates, using an innovative process design shown below in Figure 3. The overall treatment process was simplified, to enable it to be carried out within a single treatment tank; very important for operation of leachate treatment facilities at unmanned closed landfill sites, where availability of space may also be an issue. Glycerol was used as the carbon source for denitrification, since it 


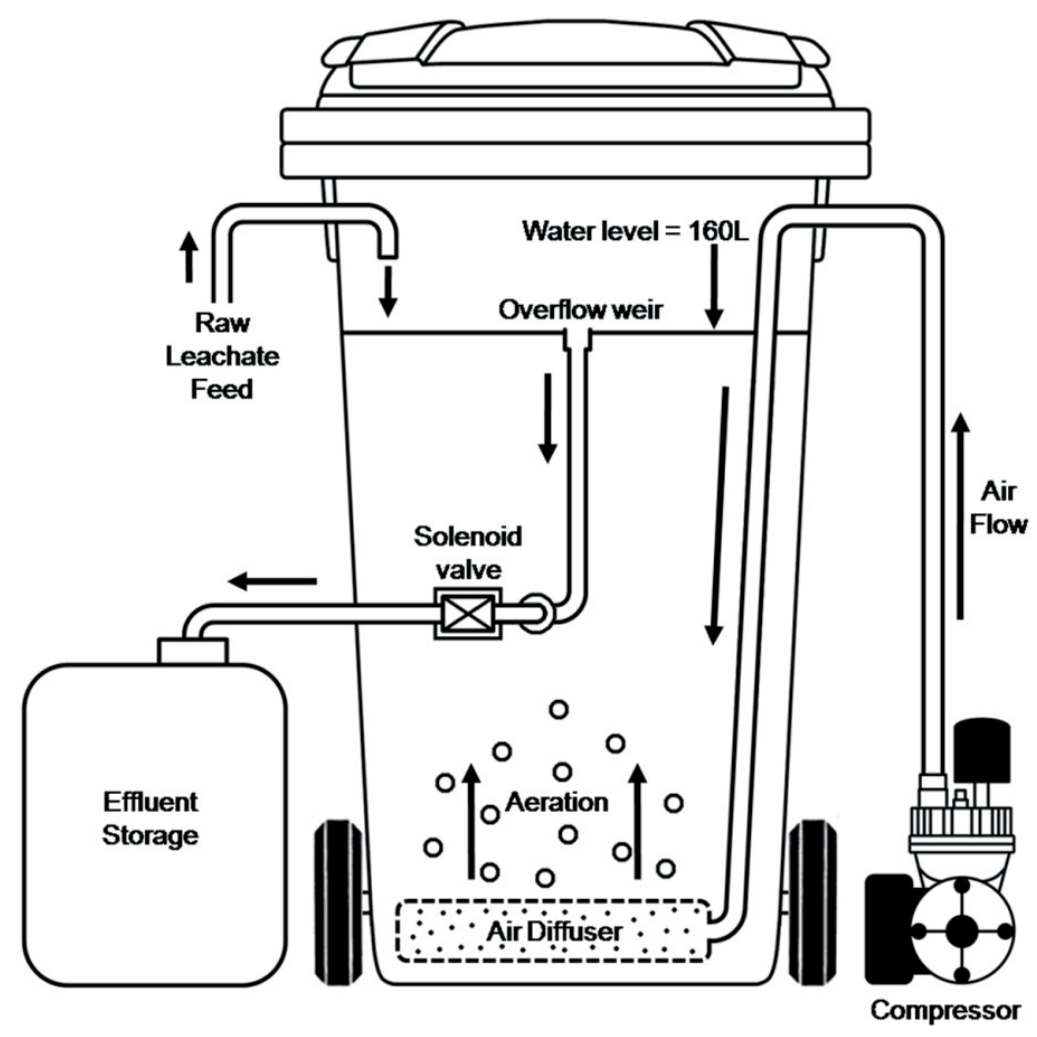

FIGURE 1: Layout of the pilot-scale SBR treatment system.

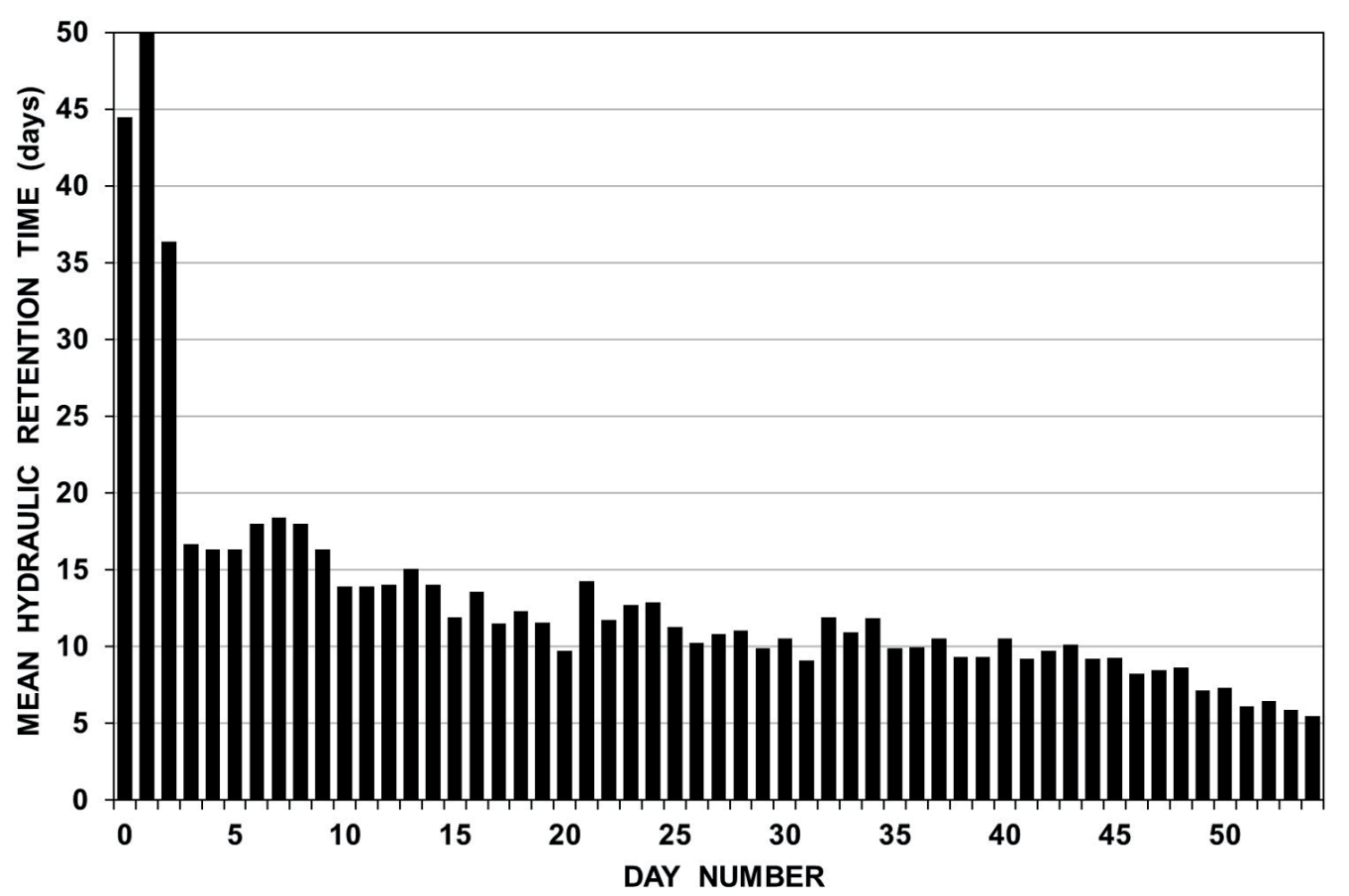

FIGURE 2: Mean hydraulic retention time (HRT, in days) during the Stage 1 trials.

is widely available as a by-product from the production of biodiesel.

Biological nitrogen removal using denitrification is common in wastewater treatment, where nitrate in effluent discharges causes concerns about eutrophication. The presence of any dissolved oxygen seriously inhibits the denitrification process, even at concentrations as low as $0.2 \mathrm{mg} / \mathrm{l}$. Denitrification operates well between $5^{\circ} \mathrm{C}$ to $40^{\circ} \mathrm{C}$, and the process is typically three times as fast as nitrification (e.g. see USEPA, 1993, and Hartley, 2013, page 42). $\mathrm{pH}$-values outside a narrow optimum range of 6.0 to 8.0 rapidly reduce rates of denitrification (Environment Agency, 


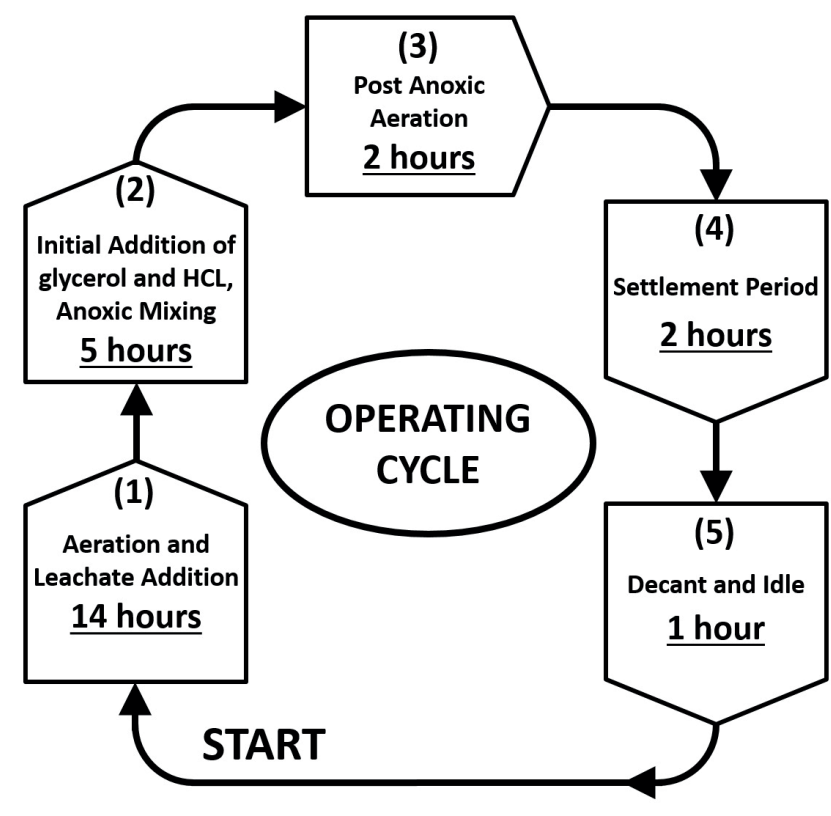

FIGURE 3: Process design for Stage 2 of the trials.

2007), and because the denitrification process releases alkalinity (3.57 grams of alkalinity as $\mathrm{CaCO}_{3}$ for every gram of nitrate- $\mathrm{N}$ reduced; see Metcalf and Eddy, 2004, page 619), it is sometimes necessary to add acid to prevent inhibition.

To incorporate an anoxic phase for denitrification, the 240-litre wheeled bin reactor was equipped with a stirrer motor (Prominent model 791503), attached to the lid. The $0.18 \mathrm{~kW}$ motor turned a small propeller at $1400 \mathrm{rpm}$, which completely mixed the contents of the reactor without aeration; allowing anoxic phases of treatment to be carried out successfully.

To allow controlled dosing of the glycerol carbon source and acid for $\mathrm{pH}$ control, a combined solution was made up which initially contained $12 \%$ glycerol waste, $4 \% \mathrm{HCl}$ and $84 \%$ water (which was later adjusted as required). To dose this solution at the start of every anoxic phase, an accurate peristaltic pump was used (Watson Marlow, model 323), via a timer. The peristaltic pump and solution container are on the desk displayed in Plate 2.

The Stage 2 treatment process again operated as a 24hour cycle with phases as follows:

(1) 14 hours: Aerobic treatment with gradual addition of leachate.

(2) 5 hours: Initial addition of glycerol (containing some acid or alkali for $\mathrm{pH}$ control as determined), and stirred Anoxic treatment to achieve denitrification.

(3) 2 hours: Post-anoxic aeration, to strip off bubbles of nitrogen generated in Phase (2), and degrade any residual glycerol.

(4) 2 hours: Quiescent sludge settlement and clarification of effluent.

(5) 1 hour: Effluent decant, then idle, before returning to Phase (1).

In order to carry out the Stage 2 trials, the trials units used for the initial treatment studies were modified as follows, to allow the process design shown in Figure 3 above to be carried out in a fully automated manner. First, a stirrer motor and propeller were attached to the lid of the treatment reactor (see the motor in Figure 4 and Plate 2 earlier), to enable the contents of the reactor to be completely mixed without any oxygen inputs, during Anoxic phases of treatment. Second, a feed bottle providing a carbon source for denitrification, in the form of diluted waste glycerol (Grabinska-Loniewska et al., 1985) was supplied. A small peristaltic pump could dose this solution into the treatment reactor in a very precise manner, under timer control at the start of each Anoxic period. Low concentrations of acid or alkali could then be added into this glycerol feed bottle, in amounts calculated to provide an accurate control of overall $\mathrm{pH}$ values in a simple manner. Figure 4 displays these additions to the modified SBR treatment reactor design.

A suitable leachate was selected from a closed landfill site in the South of England (Environment Agency, 1996), which is presently being tankered a significant distance for disposal to sewer. The leachate contained $150-160 \mathrm{mg} / \mathrm{l}$ of ammoniacal- $\mathrm{N}$, and is typical of leachates at many similar landfills in the UK (Robinson, et al., 2009; 2011).

1000 litres of leachate was collected on two separate occasions, for use in the trials, and was stored in a sealed IBC container, to be pumped into the trials feed tank as required.

The biological sludge from the Stage 1 trials was used as the seed sludge for the Stage 2 work, and during initial operation of the second trials these were operated in a nitrification-only manner, to acclimatize the bacteria to the new leachate, and also to flush through the treatment system with several bed volumes of the weaker leachate. During both sets of trials, suspended solids concentrations within the reactor were maintained well, without either significant loss or accumulation of excess biological sludge mass.

During the nitrification/denitrification phase of the combined Stage 2 treatability trials, ORP and $\mathrm{pH}$ results were used to optimize conditions for the nitrifying and denitrifying bacteria. While operating these trials, $\mathrm{pH}$ and ORP were recorded extensively during the 24-hour treatment cycle, enabling observations to be made of the effects that both nitrification and denitrification processes had on the conditions within the combined treatment reactor (Robinson, T., 2014). Outside a narrow optimum range of 6.0 to $8.0 \mathrm{pH}$-values can rapidly reduce rates of denitrification (Environment Agency, 2007).

Because in theory, during denitrification, 3.57 grams of alkalinity is produced as $\mathrm{CaCO}_{3}$ for every gram of nitrate- $\mathrm{N}$ reduced (Metcalf and Eddy, 2004; WPCF, 1983), small volumes of hydrochloric acid $\left(0.5 \mathrm{l} / \mathrm{m}^{3}\right.$ treated) were required. Additionally, the overall process could be managed using $\mathrm{pH}$ and ORP as control parameters.

Figure 5 presents results for the overall mean Hydraulic Retention Time (HRT) achieved during the entire Stage 2 trial, which from Day 0 to Day 39 was operated on a nitrification-only basis.

A feed pump failure between Days 28 and 30 meant that no leachate was dosed into the reactor during this period, but the process very rapidly achieved previous feed rates when the pump was repaired. Between Day 40 and 


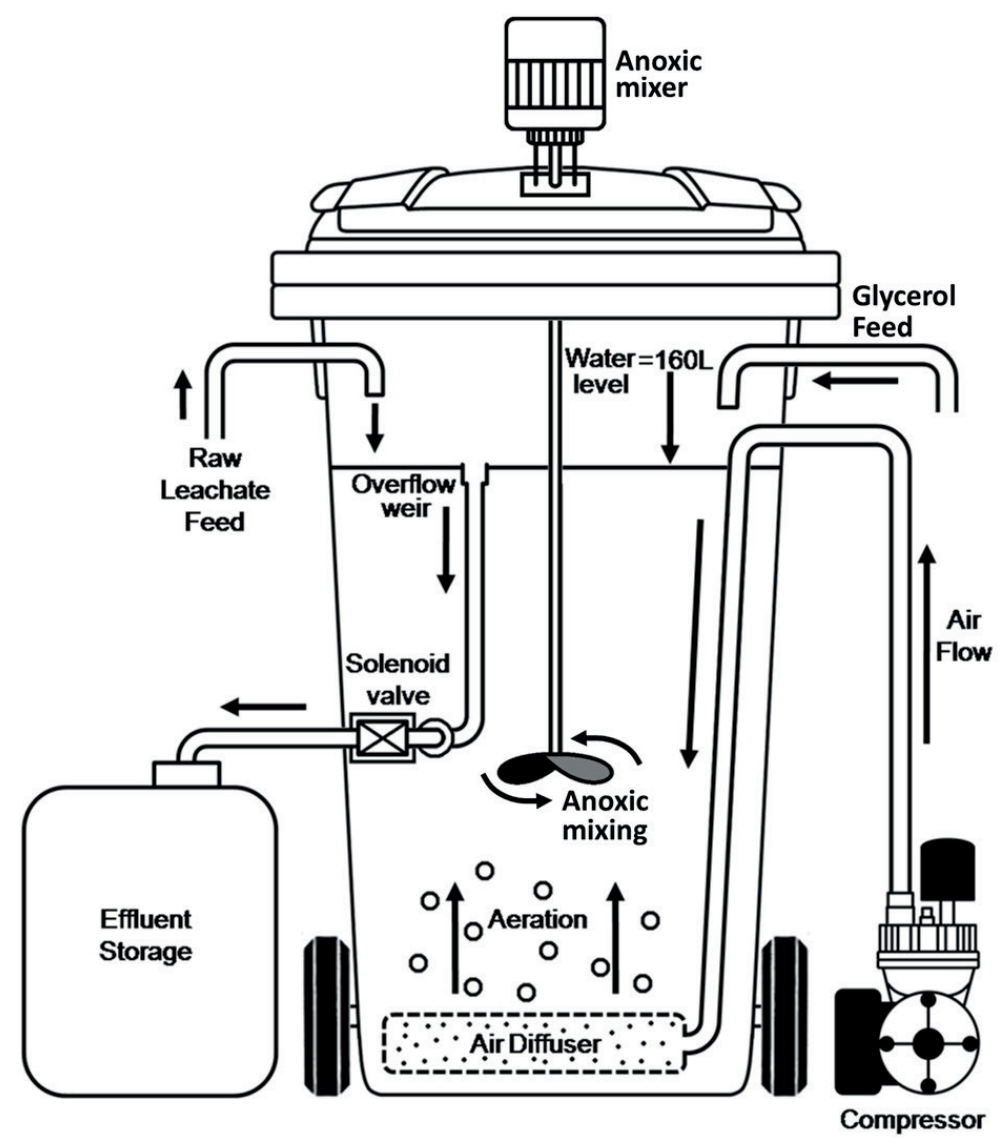

FIGURE 4: Layout of the modified SBR treatment system for Stage 2, incorporating both aeration and anoxic phases.

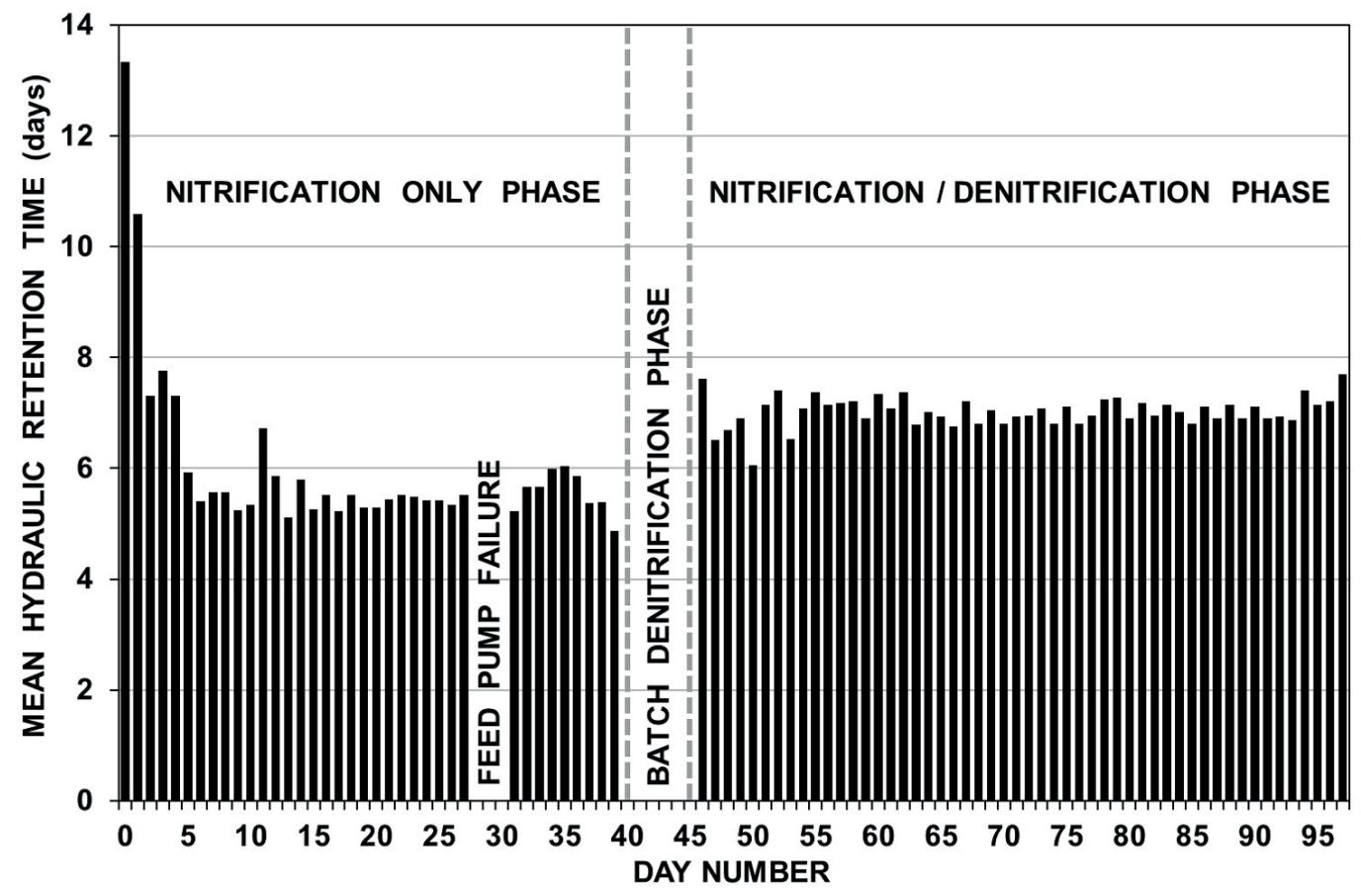

FIGURE 5: Mean Hydraulic Retention Time (HRT) during the Stage 2 trial on weaker leachate from a closed landfill site.

Day 45 , at the end of the nitrification-only phase of treatment, no leachate addition took place, as a "batch denitrification" period of treatment was carried out, following addi- tion of a small quantity (2-litres) of additional seed bacteria via thickened sludge from a full-scale leachate treatment plant in Buckinghamshire, UK, where a combined nitrifica- 
tion/denitrification process was being operated. Suitable batch doses of the glycerol were added into the reactor, sufficient to allow concentrations of nitrate- $\mathrm{N}$ and nitrite- $\mathrm{N}$ to be reduced to below detection limits, before the automated nitrification/denitrification process, and further leachate additions began on Day 46; continuing to the end of the trial on Day 97.

\section{$2.3 \mathrm{pH}$ control}

The $\mathrm{pH}$ was controlled within an optimum range of 7.2 to 7.8 by manual daily addition of measured amounts of either sodium bicarbonate (Stage 1) or hydrochloric acid (Stage 2) into the reactor. $\mathrm{pH}$-values were obtained using a handheld Palintest Micro 500 meter, which could measure to the nearest $0.01 \mathrm{pH}$, and was routinely calibrated against buffer solutions.

During the aeration period of Stage 1, the mass of sodium bicarbonate added to the reactor each day to buffer acidity was determined by weighing out an appropriate amount (using scales accurate to 0.01 gram), after observing $\mathrm{pH}$-value within the reactor.

No additions of sodium bicarbonate were required during the nitrification-only treatment of the weaker leachate in Stage 2, as the leachate itself contained sufficient alkalinity to buffer the acidity generated during nitrification of the lower concentrations of ammoniacal-N. It was only when the denitrification phase of the trials was introduced that small additions of hydrochloric acid were dosed with the daily glycerol feed solution, to effectively control $\mathrm{pH}$-values, at rates of 0.51 litres per $\mathrm{m}^{3}$ of leachate treated. This was due to the slight alkalinity produced following the denitrification phase of treatment.

\subsection{Carbon source for denitrification}

In sewage treatment, readily-degradable organic compounds in the wastewater are usually used as a carbon source for denitrification (e.g. Ludzack and Ettinger, 1962), but for leachates from landfills in methanogenic stages of decomposition containing much higher concentrations of ammoniacal-N and low levels of readily-degradable $\mathrm{BOD}_{5}$, external carbon sources must be used.

Several soluble organic compounds can be used, such as acetate, ethanol or glucose, but methanol $\left(\mathrm{CH}_{3} \mathrm{OH}\right)$ is absorbed rapidly and degraded easily, so is most commonly used in sewage treatment (Gerardi, 2006; Water Environment Federation, 1998; USEPA, 1993).

For leachate treatment with far higher concentrations of nitrate- $\mathrm{N}$ to denitrify, methanol is relatively expensive, and also has explosive/flammability issues, representing a hazard on remote and unmanned closed landfills.

For these studies, a decision was made to investigate glycerol $\left(\mathrm{C}_{3} \mathrm{H}_{8} \mathrm{O}_{3}\right)$ as a carbon source for denitrification. Glycerol is readily-degradable, available as a waste product from biodiesel production ( 1 litre is produced for every 10 litres of biodiesel), and has far lower levels of risk associated with storage and use. Although glycerol has previously been used occasionally for denitrification (e.g. see Akunna et al., 1993; Bodik et al., 2009; Grabinska-Loniewska et al., 1985), its use has increased in very recent years (including for leachate treatment - see below), and it would be a safe carbon source for use at closed landfill sites, if demonstrated to be suitable.

\subsection{ORP}

Oxidation-Reduction Potential (ORP, also known as Redox and measured in millivolts, $\mathrm{mV}$ ) is a measure of the net charge of oxidised and reduced compounds in solution, and their tendency to acquire electrons and be reduced. Nitrate and sulphate ions are examples of oxidised compounds, and ammonium ions of reduced compounds. ORP is readily measured, and managed to encourage required processes, see Table 1.

In practice, results from individual ORP instruments may be consistent, but difficult to calibrate precisely against standards, although most authors agree that results in the range $-100 \mathrm{mV}$ to $-200 \mathrm{mV}$ are ideal to achieve efficient denitrification, avoiding reduction of sulphate to release sulphide (e.g. Gerardi, 2002; Schuyler, 2013; Elefsiniotis et al., 1989).

During the Stage 2 trials, two separate devices were used, to obtain consistent and accurate ORP results. First a Palintest Micro 500 ORP monitor was used on three different days to measure ORP manually. Results were taken every minute, especially during the anoxic phase. Additionally, an automated recording device (YSI Professional Plus, ProCommll multiparameter recorder) was used on four different dates during the trial. This device had both an ORP and $\mathrm{pH}$ probe, and automatically recorded variables every fifteen minutes (Figure 6 and Figure 7 respectively).

\subsection{Lab analysis of routine samples}

Although regular daily testing was carried out manually with a $\mathrm{pH}$-meter and test strips for Ammoniacal-N, Nitrate- $\mathrm{N}$ and Nitrite- $\mathrm{N}$, giving a good indication of whether treatment was successful and stable, for more detailed analysis to be achieved samples were submitted to ALcontrol; a specialist laboratory in Chester, UK. After initial samples of leachate were sent off following on-site collection, leachate was sampled weekly from the beginning of both trials, in order to prove no changes in composition took place during storage. Sampling of treated effluent was carried out frequently throughout both the Stage 1 and Stage 2 trials, with samples being taken following settlement and clarification within the reactor. During the Stage 1 trials, settled effluent samples were taken weekly, for an overview of key determinands; ammoniacal-N, COD, BOD ${ }_{5}, T O C$, nitrate-N, nitrite- $\mathrm{N}$, alkalinity, $\mathrm{pH}$-value, sodium, and chloride. During Stage 2, when thorough observation of effluent quality was required, both settled and filtered samples (through $45 \mu \mathrm{m}$ GF/D papers) were submitted to the laboratory twice each week for the same analytical suite. The benefit of filter-

TABLE 1: Nitrification, denitrification and ORP (mV) (After Gerardi, 2002).

\begin{tabular}{l|l}
\hline ORP & Bacterial Process \\
\hline$>150 \mathrm{mV}$ & Degradation of BOD and nitrification of $\mathrm{NH}_{4}^{+}$and $\mathrm{NO}_{2}^{-}$ \\
\hline+150 to $-150 \mathrm{mV}$ & Degradation of $\mathrm{BOD}$ with $\mathrm{NO}_{2}^{-}$and $\mathrm{NO}_{3}^{-}$ \\
\hdashline$<-150 \mathrm{mV}$ & Degradation of $\mathrm{BOD}$ with $\mathrm{NH}_{4}^{+}$and $\mathrm{SO}_{4}^{2-}$ \\
\hline
\end{tabular}


ing samples through $45 \mu \mathrm{m}$ GF/D filter paper is that only results for dissolved determinands would be reported in those samples; however, there was very little difference between concentrations in filtered and unfiltered samples. Occasional, more comprehensive analysis (including the nine heavy metals) was required for leachate and effluent quality. Therefore, further samples were taken at the start, midpoint and end of both trials, to prove the consistent removal that both pilot-scale treatment systems provided (see Tables 2 and 4).

All samples were submitted to arrive at the ALcontrol Laboratory within 24 hours of sampling, for analysis. Routine laboratory protocol for analysis of such samples involved separate filtration through a $0.45 \mu \mathrm{m}$ filter upon receipt at the lab.

To determine the COD in water samples, ALcontrol Laboratories use sulphuric acid and potassium dichromate in the presence of a silver sulphate catalyst to oxidize well shaken samples. $2 \mathrm{ml}$ of sample is then added to the reagent tube and mixed. The tube is put into a heating block at $148^{\circ} \mathrm{C}$ for 2 hours. After allowing cooling, the result is read using a photometer, to a detection limit of $7 \mathrm{mg} / \mathrm{l}$.

To test for Total Organic Carbon (TOC) the samples are well shaken before being taken for analysis. The analysis is carried out by automated wet oxidation, where the $\mathrm{CO}_{2}$ produced is purged from the acidified sample and detected by a non-dispersive infrared (NDIR) detector. Following removal of the inorganic carbon, $\mathrm{CO}_{2}$ produced by persulphate oxidation is purged from the sample and detected by NDIR. The mass of $\mathrm{CO}_{2}$ produced from this reaction is proportional to the mass of TOC present in the sample. The detection limit for this analysis is $3 \mathrm{mg} / \mathrm{l}$, whilst the range is 3-125mg/l.

Analysis for dissolved metals incorporates operation of the Thermo Scientific X Series Inductively Coupled Plasma Mass Spectrometer (ICP-MS) for multi-element determination. All samples are essentially run neat, thus low levels of detection can be achieved. Following acidification, the samples in solution pass into the plasma source in a flow of argon where atomisation and ionisation occur. The quadrupole MS separates out ions by their mass to charge ratio, which is element specific. The intensity of the signal at each mass is directly proportional to the concentration of the element in question in the solution.

\section{RESULTS}

\subsection{Results from Stage 1 nitrification trials}

The pilot-scale SBR unit was seeded with bacterial sludge from a full-scale treatment plant in Southern England, which was treating a similar strength leachate.

During the period from Day 29 to Day 45, when leachate feed rate was maintained at very stable levels of 16 to 17 litres per day, a total of 271.8 litres of leachate was treated, at a mean HRT of very close to 10 days (10.01 days). By Day 43, for which detailed analysis of the effluent are provided in Table 2, a total of 561.4 litres of leachate had been treated, representing more than 3.5 bed volumes of the treatment reactor.

Table 3 presents mean concentrations for key determi- nands within the raw leachate feed and the final effluent during Stage 1. The percentage removal of these determinands highlights how successful the treatability trial was at nitrifying all ammoniacal-N to produce nitrate-N.

During the period of stable operation from Day 29 to 45 , it was necessary to add a total of 1620.5 grams of sodium bicarbonate, equivalent to 5.96 grams of $\mathrm{NaHCO}_{3}$ to every litre of leachate treated. This rate of addition can be confirmed to within 6 percent by the observed increase in concentrations of sodium from leachate to effluent ( 85 percent increase).

The Stage 1 trials performed very well indeed, achieving and maintaining complete nitrification of over $1,800 \mathrm{mg} / \mathrm{l}$ ammoniacal- $\mathrm{N}$, and substantial reduction in $\mathrm{BOD}_{20}$ and $\mathrm{BOD}_{5}$ at all times, and allowing leachate dosing rates to be increased steadily with no breakthrough of either ammoniacal-N or nitrite-N.

In practice, for a full-scale leachate treatment plant, alkalinity would not be added as sodium bicarbonate, but instead a solution of sodium hydroxide $(\mathrm{NaOH})$ would be used. A 32 per cent solution (w/w) would be most likely to be used in a temperate climate, as stronger solutions can freeze at temperatures above $5^{\circ} \mathrm{C}$. In this case, an equivalent alkalinity dosing rate would be 7.45 litres of $32 \%$ $\mathrm{NaOH}$ solution to be dosed into every cubic meter of leachate treated. This is a typical dosing rate for similar fullscale treatment plants, and data obtained from these trials would allow the volume of a suitable $\mathrm{NaOH}$ storage tank to be optimized.

\subsection{Results from the Stage 2 trials}

Treatment within the combined nitrification and denitrification phase of treatment, between Days 46 and 97, was extremely stable, with very consistent full nitrification and denitrification of $150 \mathrm{mg} / \mathrm{l}$ of ammoniacal-N during the entire 52-day period. A total of 1186.1 litres of leachate was treated, at an average rate of 22.8 litres per day.

Acidity produced during a nitrification phase, and alkalinity produced during a subsequent denitrification phase, were balanced, without excessive cyclical swings in $\mathrm{pH}$-value; this minimised any requirement for additions of $\mathrm{pH}$ control chemicals. Additions of glycerol amounted to rates much less than 1 litre of glycerol for every cubic metre of leachate treated, which would be relatively inexpensive to supply on a larger scale. $\mathrm{pH}$-values were maintained automatically by additions of very low quantities of hydrochloric acid into the daily glycerol feed.

Table 4 presents a summary of the quality of raw leachate used and of treated leachate quality during both the initial nitrification only phase of treatment, and during the later stable nitrification and denitrification phase of the Stage 2 trials.

Table 5 highlights the removal of key determinands throughout the combined nitrification and denitrification phase of the Stage 2 trials. Importantly, this table demonstrates that both ammoniacal- $\mathrm{N}$ and nitrate- $\mathrm{N}$ concentrations within the final effluent remained low, following both the nitrification and denitrification processes. Daily test strip analysis of the effluent produced throughout the trials proved that all ammoniacal- $\mathrm{N}$ within the leachate was be- 
TABLE 2: Results for quality of the raw and treated leachate during the Stage 1 trials.

\begin{tabular}{|c|c|c|c|c|c|}
\hline \multirow[b]{2}{*}{ Day } & \multicolumn{2}{|c|}{ Leachate } & \multicolumn{3}{|c|}{ Effluent } \\
\hline & $0(S)$ & $43(S)$ & $40(S)$ & $43(F)$ & $43(S)$ \\
\hline \multicolumn{6}{|l|}{ Determinand } \\
\hline COD & 3510 & 3530 & 1420 & 1440 & 1510 \\
\hline $\mathrm{BOD}_{20}$ & 499 & 330 & $<300$ & $<10$ & 29.4 \\
\hline $\mathrm{BOD}_{5}$ & 275 & 173 & $<10$ & $<5$ & 10.7 \\
\hline TOC & 1140 & 1120 & 517 & 27.6 & 534 \\
\hline fatty acids (as C) & $<10$ & $<10$ & $<10$ & $<10$ & $<10$ \\
\hline Kjeldahl-N & 1720 & 1980 & 76.9 & 177 & 172 \\
\hline ammoniacal-N & 1850 & 1820 & 0.871 & 0.485 & 0.391 \\
\hline nitrate-N & $<1.35$ & $<1.35$ & 1670 & 1700 & 1670 \\
\hline nitrite-N & $<0.304$ & $<0.304$ & $<0.304$ & $<0.304$ & $<0.152$ \\
\hline alkalinity $\left(\right.$ as $\mathrm{CaCO}_{3}$ ) & 9740 & 9420 & 236 & 140 & 150 \\
\hline pH-value & 8.11 & 8.05 & 7.73 & 7.2 & 7.11 \\
\hline chloride & 2390 & 2530 & 2440 & 2470 & 2470 \\
\hline sulphate $\left(\right.$ as $\left.\mathrm{SO}_{4}\right)$ & 513 & 517 & 564 & 603 & 598 \\
\hline phosphate (as P) & 11.3 & 11.7 & 10.5 & 10.1 & 10.1 \\
\hline conductivity $(\mu \mathrm{S} / \mathrm{cm})$ & 20,800 & 19,300 & 15,800 & 16,300 & 17,500 \\
\hline sodium & 2000 & 2090 & 3890 & 3630 & 3820 \\
\hline magnesium & 75.7 & 90.2 & 91.8 & 80.5 & 78.9 \\
\hline potassium & 1280 & 1340 & 1390 & 1360 & 1310 \\
\hline calcium & 73.1 & $<5.7$ & 102 & 101 & 98.4 \\
\hline chromium & 0.371 & 0.345 & 0.336 & 0.293 & 0.291 \\
\hline manganese & 0.381 & 0.389 & 0.048 & 0.012 & 0.082 \\
\hline iron & 0.709 & $<2.40$ & 1.57 & 1.25 & 2.44 \\
\hline nickel & 0.256 & 0.253 & 0.270 & 0.249 & 0.253 \\
\hline copper & $<0.04$ & $<0.04$ & $<0.056$ & $<0.04$ & $<0.04$ \\
\hline zinc & 0.061 & 0.042 & 0.180 & 0.105 & 0.097 \\
\hline cadmium & $<0.005$ & $<0.005$ & 0.014 & $<0.005$ & $<0.005$ \\
\hline lead & 0.0174 & 0.0148 & 0.0118 & $<0.005$ & $<0.005$ \\
\hline arsenic & 0.420 & 0.409 & 0.342 & 0.337 & 0.330 \\
\hline mercury & $<0.00002$ & $<0.00002$ & 0.00005 & 0.00003 & 0.00004 \\
\hline
\end{tabular}

Notes: All results in $\mathrm{mg} / \mathrm{l}$, except $\mathrm{pH}$-value, and conductivity $(\mu \mathrm{S} / \mathrm{cm}) /$ Alkalinity as $\mathrm{CaCO}_{3} /(\mathrm{S})=$ Settled effluent sample. $(\mathrm{F})=$ Filtered effluent sample through GF/D paper.

TABLE 3: Mean removal of key determinands during the Stage 1 trials.

\begin{tabular}{l|cccc}
\multicolumn{1}{l}{ Determinand } & $\begin{array}{c}\text { Mean } \\
\text { leachate }\end{array}$ & $\begin{array}{c}\text { Mean } \\
\text { effluent }\end{array}$ & $\begin{array}{c}\text { Mean } \\
\text { removal (\%) }\end{array}$ \\
\hline COD & 3520 & 1457 & 58.6 \\
\hdashline TOC & 1130 & 360 & 68.2 \\
\hline ammoniacal-N & 1835 & 0.6 & 99.9 \\
\hline nitrate-N & 1.35 & 1680 & $-124,344$ \\
\hline nitrite-N & $<0.304$ & $<0.304$ & 0.0 \\
\hline alkalinity (as $\left.\mathrm{CaCO}_{3}\right)$ & 9580 & 175 & 98.2 \\
\hline chloride & 2460 & 2460 & 0.0 \\
\hdashline sodium & 2045 & 3780 & -84.8 \\
\hline
\end{tabular}

Notes: Increased concentrations of sodium, due to small additions of sodium bicarbonate when controlling changes in $\mathrm{pH}$ due to the acidity created through the nitrification process. ing reduced to trace levels, whilst the denitrification phase was successfully removing nitrate-N.

The treatability trials demonstrated that a close balance could be achieved between consumption of alkalinity during nitrification of ammoniacal- $\mathrm{N}$, and release of alkalinity during the denitrification stage in the Anoxic Reactor. In both the pilot-scale trials and at full-scale, controlled additions of small volumes of hydrochloric acid were required, into the Anoxic Tank, as denitrification of the high nitrate concentrations generated quantities of alkalinity with potential to inhibit the denitrification process (at $\mathrm{pH}$ values greater than about 8.0).

Figure 6 summarizes ORP data from several 24-hour treatment cycles during the Stage 2 trials. Vertical dotted lines mark the time of the start of each individual period during the cycle (as displayed in Figure 3), and labels 
TABLE 4: Results for quality of raw and treated leachate during the Stage 2 trials.

\begin{tabular}{|c|c|c|c|c|c|}
\hline \multirow{3}{*}{$\begin{array}{l}\text { Location } \\
\text { Treatment } \\
\text { Day }\end{array}$} & \multirow{2}{*}{\multicolumn{2}{|c|}{$\begin{array}{c}\text { Raw leachate } \\
\text { FEED }\end{array}$}} & \multicolumn{3}{|c|}{ Final effluent } \\
\hline & & & \multirow{2}{*}{$\begin{array}{c}\mathrm{N} \\
37(\mathrm{~F})\end{array}$} & \multicolumn{2}{|c|}{ N plus DeN } \\
\hline & $37(S)$ & $60(S)$ & & $67(F)$ & $67(S)$ \\
\hline \multicolumn{6}{|l|}{ Determinand } \\
\hline COD & 155 & 177 & 74 & 84 & 85 \\
\hline $\mathrm{BOD}_{20}$ & $>16$ & 30 & $<30$ & $<1$ & 3.23 \\
\hline $\mathrm{BOD}_{5}$ & 8.4 & 12 & $<1$ & $<1$ & $<1$ \\
\hline TOC & 59 & 56 & 27 & 30 & 31 \\
\hline fatty acids (as C) & $<10$ & $<10$ & $<10$ & $<10$ & $<10$ \\
\hline Kjeldahl-N & 141 & 146 & 23.7 & 2.5 & 3.1 \\
\hline ammoniacal-N & 142 & 143 & $<0.2$ & $<0.2$ & 0.40 \\
\hline nitrate-N & 0.223 & 0.591 & 151 & 0.52 & $<0.06$ \\
\hline nitrite-N & 0.222 & 1.40 & $<0.015$ & $<0.015$ & $<0.015$ \\
\hline alkalinity $\left(\right.$ as $\left.\mathrm{CaCO}_{3}\right)$ & 1020 & 1030 & 75 & 325 & 325 \\
\hline $\mathrm{pH}$-value & 7.95 & 7.94 & 7.82 & 8.43 & 8.44 \\
\hline chloride & 199 & 191 & 211 & 522 & 524 \\
\hline sulphate $\left(\right.$ as $\left.\mathrm{SO}_{4}\right)$ & 34 & 39 & 42 & 34 & 35 \\
\hline phosphate (as P) & $<0.02$ & 0.026 & 6.61 & 2.36 & 2.33 \\
\hline conductivity ( $\mu \mathrm{S} / \mathrm{cm})$ & 2370 & 2420 & 1930 & 1860 & 1840 \\
\hline sodium & 179 & 198 & 208 & 287 & 293 \\
\hline magnesium & 35 & 34 & 39 & 45 & 47 \\
\hline potassium & 100 & 108 & 115 & 138 & 146 \\
\hline calcium & 127 & 187 & 170 & 250 & 256 \\
\hline chromium & 0.0065 & 0.0155 & 0.0073 & 0.0108 & 0.0112 \\
\hline manganese & 0.0056 & 0.0137 & 0.0015 & 0.0490 & 0.0590 \\
\hline iron & 4.93 & 22.6 & 0.060 & 0.027 & 0.134 \\
\hline nickel & 0.0133 & 0.0169 & 0.0160 & 0.0168 & 0.0170 \\
\hline copper & $<0.004$ & $<0.004$ & 0.015 & 0.0066 & $<0.004$ \\
\hline zinc & 0.0174 & 0.0771 & 0.0150 & 0.0093 & 0.0067 \\
\hline cadmium & $<0.0005$ & $<0.0005$ & $<0.0005$ & $<0.0005$ & $<0.0005$ \\
\hline lead & $<0.0005$ & $<0.0029$ & $<0.0005$ & $<0.0005$ & $<0.0005$ \\
\hline arsenic & 0.0063 & 0.0215 & 0.0150 & 0.0010 & 0.0012 \\
\hline mercury & $<0.00002$ & $<0.00002$ & $<0.00002$ & $<0.00002$ & $<0.00002$ \\
\hline
\end{tabular}

Notes: All results in $\mathrm{mg} / \mathrm{l}$, except $\mathrm{pH}$-value, and conductivity $(\mu \mathrm{S} / \mathrm{cm}) /$ Alkalinity as $\mathrm{CaCO}_{3} /(\mathrm{S})=$ Settled effluent sample. $(\mathrm{F})=$ Filtered effluent sample through GF/D paper / $N$ = nitrification only phase of the trial $/ N$ plus $D e N=$ nitrification and denitrification phase of the trial.

TABLE 5: Mean removal of key determinands during the nitrification and denitrification phase of the Stage 2 trials (days 46 to 97).

\begin{tabular}{l|c|c|c}
\hline Determinand & $\begin{array}{c}\text { Mean } \\
\text { feed }\end{array}$ & $\begin{array}{c}\text { Mean } \\
\text { effluent }\end{array}$ & $\begin{array}{c}\text { Mean } \\
\text { removal (\%) }\end{array}$ \\
\hline COD & 166 & 84.5 & 49.1 \\
\hline TOC & 57.5 & 30.5 & 47.0 \\
\hline ammoniacal-N & 142.5 & 0.25 & 99.8 \\
\hdashline nitrate-N & 0.407 & 0.275 & 32.4 \\
\hdashline nitrite-N & 0.811 & $<0.015$ & $>98.2$ \\
\hline alkalinity $\left(\mathrm{as}_{\mathrm{NaCO}}\right)$ & 1025 & 325 & 68.3 \\
\hline chloride & 195 & 523 & -168.2 \\
\hdashline sodium & 189 & 290 & -53.8 \\
\hline
\end{tabular}

Notes: Increased concentrations of chloride, due to small additions of hydrochloric acid when controlling changes in $\mathrm{pH}$. highlight each phase. Two different ORP instruments were used when recording ORP over 24-hour cycles, in order to increase the reliability of the readings obtained. Results from each instrument vary on specific days, but show a very clear pattern for ORP during each cycle.

During the 14-hour aeration and leachate dosing phase, ORP gradually rose, within an overall range from about $+70 \mathrm{mV}$ to $+140 \mathrm{mV}$. Dosing of the glycerol/HCL solution, 30 minutes into the Anoxic Period, caused a very rapid fall in ORP, to between $-80 \mathrm{mV}$ and $-170 \mathrm{mV}$ for the YSI instrument, and $-150 \mathrm{mV}$ to $-180 \mathrm{mV}$ for the Palintest instrument. This allowed effective denitrification to take place, although there was variation in the response times of the two instruments, and between actual values being measured.

The Post Anoxic Aeration period began at 14:00 pm. 
Sudden mixing and aeration caused a rapid increase in ORP, to $+150 \mathrm{mV}$ on the Palintest instrument (equivalent to $100 \mathrm{mV}$ on the YSI recorder). After 2 hours (16:00 pm), aeration stopped and settlement began. During this quiescent period, ORP was stable or reduced slightly. At 19:00 pm, after effluent decant, the aeration period began again and the 24-hour cycle restarted.

Figure 7 shows equivalent $\mathrm{pH}$ data during the same 24-hour periods as Figure 6 . These $\mathrm{pH}$ data reveal similar trends to the ORP graph:

- $\quad$ pH remained stable, between 7.8 and 7.9 during the aeration phase.

- After glycerol/acid addition at 09:00am a drop in $\mathrm{pH}$ is evident, to between 7.2 and 7.3; an ideal range for denitrification to occur.

- A sudden increase in $\mathrm{pH}$ to between 7.85 and 7.95 occurs during the 2 hours of the post anoxic aeration phase, possibly as carbon dioxide is stripped from solution.

- $\mathrm{pH}$-values fall steadily from 7.95 to 7.6 during the settlement/decant phase, before gradually returning to between 7.8 and 7.9 at the start of the 14 -hour aeration phase.

It is clear that $\mathrm{pH}$ and ORP can be used to optimize the operation of the treatment process, and detailed monitoring in a full-scale plant would enable additions of glycerol and acid to be optimized further, without reducing treatment efficiency.

All results from the Stage 2 trials have been extremely promising, in terms of the quality of effluent that was achieved and maintained consistently. Results for the combined treatment system, in which essentially complete removal of ammoniacal- $\mathrm{N}$ and nitrate- $\mathrm{N}$ were achieved using an innovative and relatively simple process design, demonstrated that the process has huge potential for application at relatively remote closed landfills. In instances such as these, leachates are presently being tankered long distances for disposal, at significant cost, and often with many tanker movements along small rural lanes, therefore an efficient and inexpensive on-site treatment solution would be very beneficial.

The discharge of treated leachates from such sites is coming under increased scrutiny in terms of nitrogen content, and this new combined treatment process can readily be implemented at relatively low additional cost, and can be operated with low personnel requirements for supervision on sites. One issue which may require further consideration in some locations is the increase in chloride concentrations which results from the use of low doses of hydrochloric acid for simple $\mathrm{pH}$ control. Where chloride in a discharge is an issue, then alternative acids may need to be considered.

\section{CONCLUSIONS}

The studies reported in this paper involved large pilot-scale treatment studies on leachates that are very typically produced at older, closed landfills. The leachate used contained about $160 \mathrm{mg} / \mathrm{l}$ of ammoniacal-N, and treatment sought to incorporate nitrification and denitrification processes within a single reactor, by design of an innovative process configuration, using the waste product glycerol as a carbon source, widely available as a by-product from the production of biodiesel (Bodik et al., 2009).

The paper describes the design and operation of the two stages of the trial, presents detailed analytical and operational results, and discusses the implications of these.

The first, nitrification-only stage of the trials generated very accurate process information, which is extremely valuable for the design of full-scale leachate treatment plants in many countries. Data demonstrated the value and operation of the pilot scale units, and showed that similar trials can be very valuable as a first stage in the design of full-scale treatment plants. In particular, they are able to demonstrate that specific leachates being tested do not contain any inhibitory substance, before large sums of money are spent developing a full-scale treatment plant.

The second stage of the trials was especially valuable, in which an innovative process design was developed and tested to provide a relatively simple, single-tank, treatment plant, which can provide full nitrification and denitrification of weaker leachates (ammoniacal-N from 150 to $200 \mathrm{mg} / \mathrm{l}$ ) at closed landfill sites. The fact that the process can operate with only minimal supervision, is extremely important at all closed landfill sites, and will be tested at larger scale in the near future. The pilot-scale studies have provided sufficiently detailed data to allow a full-scale treatment plant to be designed.

In conclusion to the Stage 2 combined nitrification and denitrification trials, several important findings have been highlighted, which will be valuable in the consideration of managing those leachates produced at closed landfills in the future:

For relatively weak leachates from old landfill sites (ammoniacal-N of $100-200 \mathrm{mg} / \mathrm{l})$, nitrification, denitrification, post-aeration and effluent clarification/decant can all be achieved simply and sequentially in a 24-hour cycle within a single reactor tank.

The acidity produced during a nitrification phase, and alkalinity produced during a subsequent denitrification phase, can be balanced, without excessive cyclical swings in $\mathrm{pH}$-value which might inhibit the overall treatment process. This would minimise requirements for additions of $\mathrm{pH}$ control chemicals.

A biomass of denitrifying bacteria can be acclimatised successfully to use waste glycerol from biodiesel production, as a carbon source for denitrification, and that ORP can be used as a control parameter for the process.

The whole treatment process can be fully automated in a simple way, both in the laboratory studies, and for fullscale treatment systems on closed landfill sites.

Complete removal of ammoniacal- $\mathrm{N}$ and nitrate- $\mathrm{N}$ have been achieved using an innovative and relatively simple process design within a single reactor setup. This study demonstrated that the combined nitrification and denitrification process within a single reactor has huge potential for application at old, small and relatively remote closed landfills. This new process could readily be implemented at relatively low cost, and operated with low personnel re- 


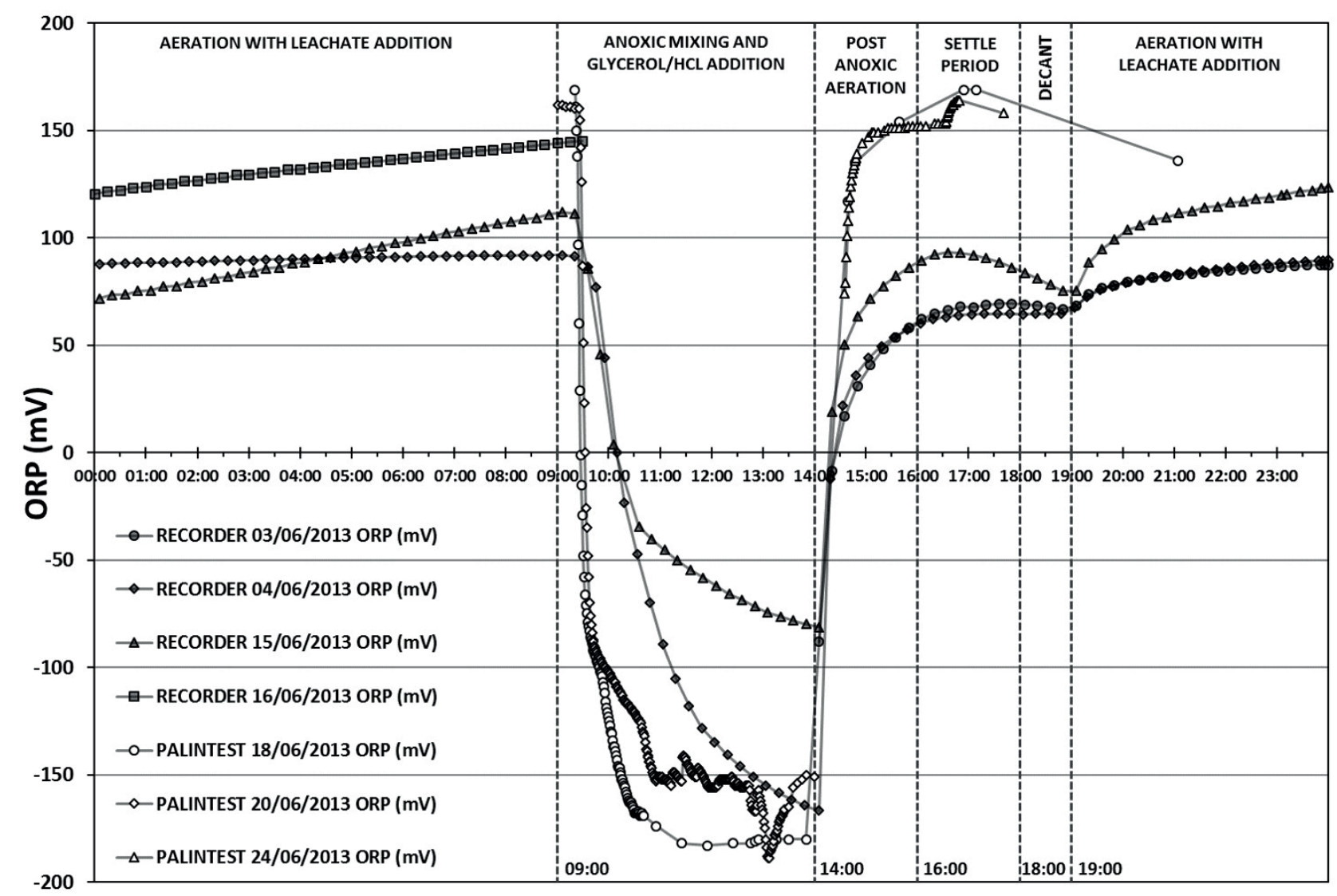

FIGURE 6: Changes in ORP during the 24-hour operating cycle of the Stage 2 trials, using data from two ORP devices on seven different days.

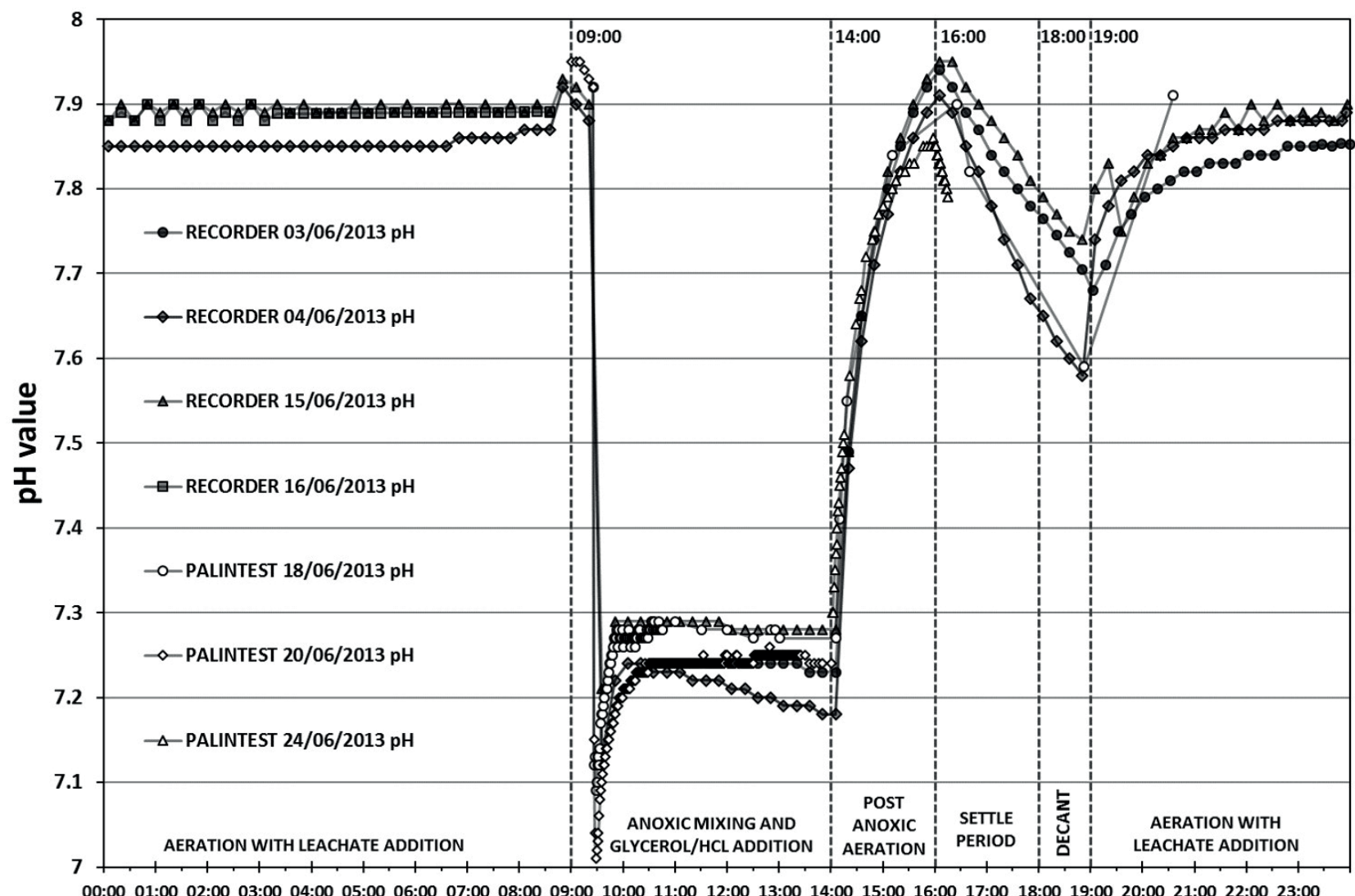

FIGURE 7: Changes in pH during the 24-hour operating cycle of the Stage 2 trials, using data from two pH devices on seven different days. 
quirements for supervision. This is in contrast to an expensive treatment plant with separate reactors for aeration, anoxic treatment, post-aeration etc., where reactors must be sized and constructed before the plant is commissioned, and full-time supervision and monitoring is needed.

\section{ACKNOWLEDGEMENTS}

The author would like to acknowledge the help and assistance received from colleagues at SKM Enviros in undertaking this experimental study, which primarily represents a detailed research study undertaken as a final year thesis at the University of East Anglia (see Robinson, 2014). Many thanks to my supervisor, Professor Kevin Hiscock at the University of East Anglia, for his support and guidance.

Viridor Waste Management and East Sussex County Council were each extremely helpful in providing access to data and to landfill sites for collection of leachate samples.

\section{REFERENCES}

Akunna, J.C., C. Bizeau and R. Moletta, 1993, Nitrate and nitrite reductions with anaerobic sludge using various carbon sources: glucose, glycerol, acetic acid, lactic acid and methanol, Water Research, 27, 1303-1312.

Bodik, I., A. Blstakova, S. Sedlacek and M. Hutnan (2009). Biodiesel waste as source of organic carbon for municipal WWTP denitrification, Bioresource Technology, 100, 2452-2456.

Christensen, T.H., 2011, Landfilling: Leachate Treatment, Chapter 10.11 in: Christensen, T.H., Solid Waste Management and Technology, Blackwell Publishing Ltd, John Wiley \& Sons, ISBN 9781405175173, 1026pp.

Elefsiniotis, P., R. Manohanaran and D.S. Mavinic, 1989, The effects of sludge recylce ratio on nitrification-denitrification performance in biological treatment of leachate. Environmental Technology Letters, 10, 1040-1050, p.1043.

Environment Agency (1996). A Review of the Composition of Leachates from Domestic Wastes in Landfill Sites. Report No. CWM 072/95, published by the Waste Technical Division of the Environment Agency, in the series "The Technical Aspects of Controlled Waste Management", 550pp, August 1996.

Environment Agency (2007). Guidance for the treatment of landfill leachate. Sector Guidance Note IPPC S5.03, February 2007. 182pp.

Gerardi, M.H. (2002), Settleability problems and loss of solids in the activated sludge process, John Wiley and Sons, USA and Canada, Wastewater Microbiology Series, ISBN 0-471-20694-6, 179pp.

Gerardi, M.H. (2006), Wastewater Bacteria, John Wiley and Sons, USA and Canada, Wastewater Microbiology Series, ISBN 0-471-206911, 255pp.

Grabinska-Loniewska, A., T. Slomczynski, and Z. Kanska (1985). Denitrification studies with glycerol as a carbon source, Water Research, 19, 1471-1477.

Hartley, K. (2013), Tuning Biological Nutrient Removal Plants, IWA Publishing, London, UK, 246pp.

Kjeldsen, P., M.A. Barlaz, A.P. Rooker, A. Baun, A. Ledin and T.H. Christensen (2002). Present and Long-Term Composition of MSW Landfill Leachate: A Review, Critical Reviews in Environmental Science and Technology, 32, 297-336.
Ludzack, F.J. and M.B. Ettinger, 1962. Controlling operation to minimize activated sludge effluent nitrogen. Journal of the Water Pollution Control Federation, 34, 920-931.

Metcalf \& Eddy (2004), Updated by G. Tchobanoglous, F.L. Burton, and H.D. Stensel, Wastewater engineering, treatment and reuse, Mc Graw Hill, New York, 4.

Robinson, H., 2007, The composition of leachates from very large landfills: An international review, Communications in Waste and Resource Management, 8, 19-32.

Robinson, H. D., and Formby, R. W. (2009). The use of pilot-scale trials in the design of on-site leachate treatment plants. Proceedings of Sardinia 2009, The Twelfth International Waste Management and Landfill Symposium, Cagliari, Italy; 5-9 October 2009.

Robinson, H., Carville, M., Bailey, P., Farrow, S., Jones, D. and L.Gibbs (2011). Full-scale treatment of landfill leachates with full nitrification and denitrification. Proceedings of Sardinia 2011, Thirteenth International Waste Management and Landfill Symposium, S. Margherita di Pula, Cagliari, Italy; 3 - 7 October 2011.

Robinson, H., Wilson, K., Stokes, A., Olufsen, J., Robinson, T. (2017). Recent state-of-the-art leachate treatment plants in eastern England. Paper presented to Sardinia 2017, the Sixteenth International Waste Management and Landfill Symposium, S.Marguerita di Pula, Cagliari, Italy, 2 - 6 October 2017, in Proceedings.

Robinson, T. (2013). Aerobic Biological Treatability Studies on Landfill Leachate using Nitrification and Denitrification. Paper presented to Sardinia 2013, the Fourteenth International Waste Management and Landfill Symposium, S.Marguerita di Pula, Cagliari, Italy, 30 September - 4 October 2013, 9pp, in Proceedings.

Robinson, T. (2014). Aerobic Biological Treatability Studies on Landfill Leachate using Nitrification and Denitrification. Final Year Dissertation Project 2014, School of Environmental Sciences, University of East Anglia, Norwich, UK, 100 pages, Available from the UEA Library.

Robinson, T. (2015). Use of pilot-scale treatability trials in the design of full-scale leachate treatment plants. Paper presented to Sardinia 2015, the Fifteenth International Waste Management and Landfill Symposium, S.Marguerita di Pula, Cagliari, Italy, 5 - 9 October 2015, 128pp in Proceedings.

Robinson, T. (2017). Robust and reliable treatment of leachate at a closed landfill site in Sussex, UK. Paper presented to Sardinia 2017, the Sixteenth International Waste Management and Landfill Symposium, S.Marguerita di Pula, Cagliari, Italy, 2 - 6 October 2017, in Proceedings.

Shuyler, R.G., 2013, What every operator should know about ORP. Water Environment and Technology, January 2013, 25, 68-69.

United States Environmental Protection Agency (1993), Nitrogen Control Manual. Office of Research and Development, U.S. Environmental Protection Agency, Cincinnati, Ohio, USA, Report EPA/625/R-93/010, 311pp.

Water Environment Federation (1998), Biological and chemical systems for nutrient removal, Water Environment Federation, USA, ISBN 1-57278-123-8, 399pp.

Water Pollution Control Federation (1983), Nutrient Control: Manual of Practice FD-7, Facilities Design, WPCF, Alexandria, VA, USA, ISBN 0-943244-44-7, 205pp.

Wilson, K.S., Robinson, H., Robinson, T., Sibley, R., and Carville, M.S. (2015). Treatment of leachate from a closed landfill in West Sussex, UK. Paper presented to Sardinia 2015, the Fifteenth International Waste Management and Landfill Symposium, S.Marguerita di Pula, Cagliari, Italy, 5 - 9 October 2015, pp285 in Proceedings. 